\title{
In Search of Hope in J.M. Coetzee's Diary of a Bad Year
}

\begin{abstract}
The article discusses J.M. Coetzee's Diary of a Bad Year to argue that although the main protagonist's views upon social, ethical, political, and scientific matters may be described as rather pessimistic, the novel still portrays artistic creation as a source of solace, hope, and a motivation for improvement in human life. The validity of the protagonist's despondent outlook upon human life is undermined by the tripartite composition of the narrative, in which his opinions are questioned when juxtaposed with the alternative views voiced by the other characters. It is argued in particular that the story narrated in the novel reinforces the image of the positive role of literature in human existence.
\end{abstract}

Keywords: J.M. Coetzee, Diary of a Bad Year, hope

W poszukiwaniu nadziei w Diary of a Bad Year J.M. Coetzeego

Streszczenie: Niniejszy artykuł omawia Diary of a Bad Year J.M. Coetzeego w celu wykazania, że chociaż poglądy głównego bohatera na kwestie społeczne, etyczne, polityczne i naukowe można określić jako dość pesymistyczne, powieść przedstawia jednak twórczość artystyczną jako źródło ukojenia, nadziei i motywację do doskonalenia w życiu człowieka. Zasadność posępnego spojrzenia głównego bohatera na życie ludzkie jest zakwestionowana przez trójdzielną kompozycję narracji, w której jego opinie są podważane w zestawieniu z alternatywnymi poglądami pozostałych postaci. Tekst w szczególności dowodzi, że ukazana w powieści historia bohaterów umacnia obraz pozytywnej roli literatury w ludzkim istnieniu.

Słowa kluczowe: J.M. Coetzee, Diary of a Bad Year, nadzieja

J.M. Coetzee's fiction has been often discussed in the context of ethical problems inherent in his works. Discussions on Coetzee's prose with reference to the significance of literature in our lives have been undertaken for instance by Derek Attridge in his monograph J.M. Coetzee and the Ethics of Reading ${ }^{1}$ and Peter McDonald in his article The Ethics of Reading and the Question of the Novel:

\footnotetext{
${ }^{1}$ D. Attridge, J.M. Coetzee and the Ethics of Reading, Chicago-London 2004.
} 
The Challenge of J.M. Coetzee's Diary of a Bad Year. ${ }^{2}$ This article focuses on one of Coetzee's novels from the 21st century - Diary of a Bad Year ${ }^{3}$ from 2007. It will analyse the vision of human life emerging from the novel, with the focus on selected problems which are referred to in Diary of a Bad Year in the context of science, philosophy and literature. The aim of the article is to argue that despite its frequently pessimistic depiction of problems of contemporary society, the novel offers a promise of consolation and hope available through artistic creation.

Diary of a Bad Year consists of two major parts, the pages of which have a tripartite composition. The division into three sections gives the novel an unusual visual layout. In the first part of the novel, entitled Strong Opinions. 12 September 2005 - 31 May 2006, the first sections present the main protagonist's "reasonable" opinions in the form of essays. In the second part of the novel, the first sections convey the protagonist's "soft opinions," i.e. his memories, impressions, dreams, and speculations on art in general and literature in particular. The protagonist, whose name may be John C., but who is usually referred to as "Señor C," "El Señor," "Juan C," "J.C.," or just "C.," is a 72-year-old writer who emigrated to Australia from South Africa. He is about to publish his newest manuscript, which contains his opinions on various contemporary issues, including human values, society, politics, environment, philosophy, literature and science. John C. may suffer from Parkinson's disease; ${ }^{4}$ he has lost fine muscular control, which makes it difficult for him to type his book. ${ }^{5} \mathrm{He}$ records his essays using a Dictaphone, from which it is possible to write down the text of his manuscript. One day he meets his neighbour, Anya, in a common laundry room located in the building they live in. She is a 29 -year-old woman who immediately attracts John C.'s attention, initially mostly due to her physical attractiveness. Since they live in the same building, they accidentally meet again in a park located in the vicinity of their premises. On this occasion, John C. asks Anya to start to work for him as a typist to write down his recorded opinions. Anya's acceptance of this proposal leads to their frequent interactions during which Anya types John C.'s manuscript and they both get to know each other's life and values. The process of Anya and John C.'s getting to know each other is revealed in the second sections of the novel. The style of these sections resembles diary entries, in which the characters - either John C. or Anya - present their conversations and impressions written in the firstperson narration. In the meantime Anya also discusses her new acquaintance with her partner, 42-year-old Alan, who works as an investment consultant. The third sections in the novel reveal Anya and Alan's conversations about John C., with frequent references to his life and opinions. In this way, Diary of a Bad Year focuses on the views and interactions between its three main characters. Apart from the opinions presented in the first sections, Diary of a Bad Year offers alternative

2 P.D. McDonald, The Ethics of Reading and the Question of the Novel: The Challenge of J.M. Coetzee's Diary of a Bad Year, "Novel: A Forum on Fiction” 2010, Issue 3.

3 J.M. Coetzee, Diary of a Bad Year, New York 2008.

${ }^{4}$ Cf. St. Murray, Allegories of the Bioethical: Reading J.M. Coetzee's Diary of a Bad Year, "Journal of Medical Humanities" 2014, Issue 35, p. 330.

5 J.M. Coetzee, op. cit., p. 163. 
narrations from the first-person points of view, often in conflict with each other, voiced by Anya and Alan in the second and third sections.

The tripartite composition, in which each section reveals a different perspective, is frequently discussed in literary criticism from various vantage points. In her article "Do you think I can't read between the lines?": Discourse of the Unsaid in J.M. Coetzee's Diary of a Bad Year, Rachael Isom employs the pragmatic philosophy of language and Bakhtinian novelistic theory to argue that the novel emphasises "the nuances inherent in the simplest of interpersonal communication" due to the interplay of interpretation and conjecture inextricably connected with conversational exchange. ${ }^{6} \mathrm{H}$. Porter Abbott in his article Time, Narrative, Life, Death, \& Text-Type Distinctions: The Example of Coetzee's Diary of a Bad Year focuses on the prevalence of the essayistic parts in the novel, which dominate over the other parts that exhibit a distinctive feature of fiction characterised as "the internal temporality": in contrast to the first sections, the second and third sections disclose "stories that unfold over time."7 Peter McDonald discusses biographical and historical facts pertinent to the analysis of the essays and conversations in the novel in his article The Ethics of Reading and the Question of the Novel: The Challenge of J.M. Coetzee's Diary of a Bad Year. ${ }^{8}$ Benjamin Ogden's article The Coming into Being of Literature: How J.M. Coetzee's Diary of a Bad Year Thinks through the Novel investigates how the unusual framework of the novel may impact the process of reading and interpreting its content. ${ }^{9}$ Related issues involving the impact of the form on the interpretation of the characters' conversations, interactions and essays are raised by Johan Geertsema in his chapter Diary of a Bad Year (2007), ${ }^{10}$ by Ana Falcato in her article Modernist Realism and its Enemies: John Coetzee and Philosophy ${ }^{11}$ and by Jonathan Lear in his chapter Ethical Thought and the Problem of Communication. ${ }^{12}$

The multiplicity of narrations and perspectives actualizes one of the main tenets of postmodernism about the plurality and equality of heterogeneous voices. ${ }^{13}$ The interactions and discussions between different subjects reveal the relative and truly subjective character of their opinions. ${ }^{14}$ Bringing into light this relative status of the characters' opinions may encourage the reader to confront them

${ }^{6}$ R. Isom, "Do you think I can't read between the lines?": Discourse of the Unsaid in J.M. Coetzee's Diary of a Bad Year, "The Journal of Commonwealth Literature" 2018, Issue 1, p. 8.

${ }^{7}$ H.P. Abbott, Time, Narrative, Life, Death, \& Text-Type Distinctions: The Example of Coetzee's Diary of a Bad Year, "Narrative" 2011, Issue 2, p. 188.

${ }^{8}$ P.D. McDonald, op. cit.

9 B.H. Ogden, The Coming into Being of Literature: How J.M. Coetzee's Diary of a Bad Year Thinks through the Novel, "Novel: A Forum on Fiction" 2010, Issue 3.

10 J. Geertsema, Diary of a Bad Year (2007) [in:] A Companion to the Works of J.M. Coetzee, ed. T. Mehigan, Rochester (NY) 2011.

11 A. Falcato, Modernist Realism and its Enemies: John Coetzee and Philosophy, "Aisthema, International Journal" 2015, Issue 2.

12 J. Lear, Ethical Thought and the Problem of Communication [in:] J.M. Coetzee and Ethics: Philosophical Perspectives on Literature, eds. A. Leist, P. Singer, New York 2010.

13 Cf. B. McHale, Postmodernist Fiction, London-New York 1987, p. 166.

14 J. Geertsema, op. cit., p. 218. 
with his or her own views on the matters discussed in the novel. ${ }^{15}$ Due to the coexistence of different voices represented by John C., Anya and Alan, the novel may be read as exemplifying the Bakhtinian concepts of "interanimation of languages"16 and of "heteroglossia." "17 Furthermore, Diary of a Bad Year has been read as an illustration of the process of "novelization" since it "develops and grows exactly by renewing and thereby perpetuating older genres within itself." 18 The opinions presented in the first sections of the novel include elements characteristic of various genres, e.g. a diary, a philosophical treatise, articles in literary criticism or cultural and religious studies, a political disquisition or a journalistic report on social issues, but they all share the dominant quality of the essay. ${ }^{19}$ These opinions are incorporated into the narrative of the novel, in which their topics are also discussed by the two other characters in the context of interactions between them. The embedding of various genres within the narration of the novel transgresses traditional genre classifications. ${ }^{20}$ This unusual composition is responsible for labelling Diary of a Bad Year a "hybrid novel." 21

It must be acknowledged that the status of the opinions expressed in the first sections is quite uncertain. The problem of ascertaining whether they could be considered the opinions of the author of the novel himself is raised and discussed by various authors, including David Attwell, ${ }^{22}$ Johan Geertsema, ${ }^{23}$ and Peter McDonald. ${ }^{24}$ These conjectures are validated by the affinity of the initial letters in the names of the protagonist and the author of the novel: "J.C." may stand both for John C. or Juan C. ${ }^{25}$ and John Coetzee. ${ }^{26}$ Another clue to support the identification of the protagonist's opinions with Coetzee's views may be found in some passages in the novel, in which John C. states that it is safer for a renowned author not to voice his opinions openly in public but to express them through his own art. ${ }^{27}$ Nonetheless, the most important argument comes from the parallels between John C.'s

15 Ibid., p. 219; A. Falcato, op. cit., p. 4.

${ }^{16}$ M. Bakhtin, The Dialogic Imagination: Four Essays by M.M. Bakhtin. ed. M. Holquist, Austin 1981, p. 47 [in:] R. Isom, op. cit., p. 8.

17 Ibid., p. 13; B.H. Ogden, op. cit., p. 474; cf. B. McHale, op. cit., p. 166-171.

18 M. Bakhtin, op. cit., p. 4-27 [in:] J. Geertsema, op. cit., p. 216.

19 Cf. H.P. Abbott, op. cit., p. 190.

20 B. Macaskill, Charting J.M.Coetzee's Middle Voice, "Contemporary Literature” 1994, Issue 3 (Autumn 1994), p. 456-457 [in:] J. Geertsema, op. cit., p. 211.

21 G. Maziarczyk G, An Utterly Contemporary Work of Fiction? J.M. Coetzee's Diary of a Bad Year [in:] Generic Instability and Identity in the Contemporary Novel, eds. M. Gonzalez, M.O. Pittin-Hedon, Newcastle upon Tyne 2010, p. 46; T. Dancer, Between Belief and Knowledge: J.M. Coetzee and the Present of Reading, "Minnesota Review" 2011, Issue 77, p. 140; M.J. López, Acts of Visitation: The Narrative of J.M. Coetzee, Amsterdam 2011, p. 286 [in:] R. Isom, op. cit., p. 7.

22 D. Attwell, Mastering Authority: J.M. Coetzee's Diary of a Bad Year, "Social Dynamics" 2010, Issue 1.

23 J. Geertsema, op. cit., p. 208.

24 P.D. McDonald, op. cit., p. 494-497.

25 J.M. Coetzee, op. cit., p. 165.

${ }^{26}$ M. Woessner, Beyond Realism. Coetzee's Post-Secular Imagination [in:] Beyond the Ancient Quarrel. Literature, Philosophy, and J.M. Coetzee, eds. P. Hayes, J. Wilm, Oxford 2017, p. 156.

27 J.M. Coetzee, op. cit., p. 9, 127; J.M. Coetzee, Giving Offense: Essays on Censorship. Chicago, London, 1996, p. 84 [in:] J. Geertsema, op. cit., p. 214, cf. p. 217. 
opinions and the actual worldview of J.M. Coetzee. As stated by David Attwell, "anyone who knows anything about Coetzee's work and reputation will know that J.C.'s views are recognisably Coetzee's." 28 The parallels between John C. and J.M. Coetzee are the reason why Diary of a Bad Year is enumerated by $\mathrm{H}$. Porter Abbott among Coetzee's "performative hybrids of fact and fiction" 29 and why it invites discussion on the status of fiction (undertaken, for instance, by Peter McDonald. ${ }^{30}$ )

The opinions presented in the first sections of the first part of the novel, typed by Anya, are to be included in a book with the provisional title Strong Opinions announced by a German publishing house. In the forthcoming book John C. and five other contributors "from various countries (...) pronounce on what is wrong with today's world." 31 These first sections of the novel, which present John C.'s worldview, usually portray human life in somewhat pessimistic terms, as revealed in the vast array of his opinions about politics, society, social norms and common human values or the meaning of human life. The air of despondency in his essays has been already commented upon by some literary scholars. As argued by Stuart Murray in his article Allegories of the Bioethical: Reading J.M. Coetzee's Diary of a Bad Year, the novel abounds in discussions on ethical issues, whose central themes revolve around "the incommensurability of multiple voices and genres organized around suffering, sickness, senescence, and, ultimately, death." ${ }^{32}$ Murray draws attention to "JC's own ineffable suffering, which confronts the limits of language," but it is probably also reflected in JC's essays when he discusses the suffering of animals. ${ }^{33}$ Benjamin Ogden also remarks on the "bleak nihilism" of John C.'s views. ${ }^{34}$ This opinion about John C.'s nihilistic bleakness is well justified in the light of the arguments presented in his essays.

John C. has a rather disheartening opinion about human nature. He believes that "human nature (...) is fallen, vicious, predatory," 35 which he indicates as a reason why people are often unable to cooperate with each other. This vision of human nature evokes Thomas Hobbes's description of humanity in the state of nature before entering a social contract aimed at regulating human relations within acceptable social norms. ${ }^{36}$ John C. refers to the bestial nature of humans and the inimical relations between them, quoting the ancient maxim "homo homini lupus"37 often associated with Thomas Hobbes. ${ }^{38} \mathrm{He}$ also raises the issue of the animal nature of

\footnotetext{
${ }^{28}$ D. Attwell, op. cit., p. 216.

29 H.P. Abbott, op. cit., p. 197.

30 P.D. McDonald, op. cit.

31 J.M. Coetzee, op. cit., p. 21.

32 St. Murray, op. cit., p. 327.

33 Ibid., p. 331.

34 B.H. Ogden, op. cit., p. 481.

35 J.M. Coetzee, op. cit., p. 81.

${ }^{36}$ Cf. Th. Hobbes, Leviathan or, The Matter, Form, and Power of a Commonwealth, London 1839, especially chapters 13 and 14 .

37 J.M. Coetzee, op. cit., p. 81.

${ }^{38}$ Cf. J. Szczepański, Homo homini deus est - homo homini lupus est. Kilka uwag o naturze ludzkiej wedtug Hobbesa, "Archiwum Historii Filozofii i Myśli Społecznej” 2013, Issue 58.
} 
humans while discussing languages and describing them as ultimately "alien to our animal being." 39

In a similar vein, John C. highlights ethical problems deep-rooted in meat consumption. The prevalent non-vegetarian habits of people across the world are responsible for raising animals in inadequate conditions in the process of food production. Yet, even more controversial are the atrocious methods of killing animals in slaughterhouses, e.g. slashing the hind tendons of cattle to make it easier to control them or stabbing their eyes with a knife to twist their head before cutting their throat in one of Egyptian abattoirs in Port Said. ${ }^{40}$ As argued by Joseph Napolitano in his article "Mr Melancholy and Mr Magpie": The Lives of Animals in J.M. Coetzee's Diary of a Bad Year, Coetzee's novel blurs the distinction between human and non-human animals. ${ }^{41}$ Indeed, the novel shows how both types of animals are "united in their mortality," a question which is also raised in Coetzee's Disgrace..$^{42}$ The acknowledgment of the similar biological nature of human and non-human animals is supported by frequent references to the theory of evolution in Diary of a Bad Year. This approach is reflected in questioning the superiority of the anthropocentric viewpoint. Although John C. states that "[h]uman reason (...) is universal reason, ${ }^{, 43}$ he has doubts concerning the alleged supremacy of human reason in the universe. His observations make him pose an important question about the role of reason in human survival in a possible evolutionary contest with viruses: "What if the contest [with viruses] to see on whose terms warm-blooded life will continue on this planet does not prove human reason to be the winner?" 44

John C.'s critical attitude towards the world he lives in is also noticeable in his discussion on political matters. He exhibits some scepticism towards democracy since he presents it as a totalitarian system in the sense that it is impossible to escape democracy in Western society. Any criticism of the current political situation must take place within the limits of a democratic society, e.g. by putting oneself forward as a candidate in a democratic election to introduce changes within the limits of democracy. In other words, democracy is totalitarian since it "does not

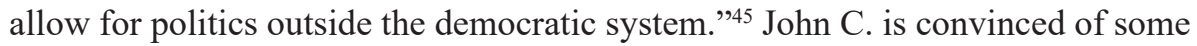
duplicity in contemporary politics, which upholds two standards of value, yet of different importance: absolute or relative. The relative standards include ideologies of morality, religion, and natural law. These ideologies are treated as relative values, which can be infringed and used instrumentally in order to uphold the absolute "interest of self-preservation." ${ }^{46}$ To give an example of this hypocrisy, he mentions that some Christian citizens accept "the use of torture in the inter-

39 J.M. Coetzee, op. cit., p. 197.

40 Ibid., p. 64-65.

41 J.D. Napolitano, "Mr Melancholy and Mr Magpie”: The Lives of Animals in J.M. Coetzee's Diary of a Bad Year, "Safundi: The Journal of South African and American Studies" 2010, Issue 1-2.

42 Ibid., p. 66.

43 J.M. Coetzee, op. cit., p. 70.

${ }^{44}$ Ibid., p. 71.

45 Ibid., p. 15.

46 Ibid., p. 17. 
rogation of prisoners. ${ }^{947}$ Although the procedure of torture clashes with Christian values, torturing is accepted by those Christians who find it "necessary to protect the public from enemies of the state." 48 John C. also has reservations about the new anti-terrorist legislation, introduced in Australia as well as Britain and the United States, which in his opinion infringes civil liberties. He finds it accurate to describe as "hysterical" the reactions to terrorist attacks exhibited by the governments in these countries..$^{49}$ In particular, the new rules prohibit "speaking favourably of terrorism," which the author of the "strong opinions" considers to be "a curb on freedom of speech." ${ }^{50} \mathrm{He}$ also notices the tragedy in the position of suicide bombers who resort to ineluctable death as the only accessible form of reaction to calamities they experienced themselves when watching their family die in military conflicts. ${ }^{51}$

Nor does John C. find consolation in another area which has been traditionally viewed as a source of solace, i.e. in religion. He divides religious systems into two kinds but does not support either option. The first type of religions are those which accept the existence of the soul after death; in these religions "the soul, that which the I calls 'I', continues to exist as itself after the body dies." 52 The second type of religions comprises those systems which reject the existence of the soul after death; in these systems "the 'I' ceases to exist as itself and is absorbed into some greater soul." ${ }^{3}$ The protagonist does not delve into this second type, but it seems he might have in mind systems such as Buddhism. John C. concentrates mostly on the first type, choosing the Christian religion as a primary example of this class. The protagonist criticises Christianity for offering only a very vague idea of what afterlife may look like. He claims that Christian visions of the afterlife are not very informative and they lack important details. Instead, in those visions "there are only vague images of harps and choirs." 54 John C. states that the Christian religion gives a rather nebulous idea of what happens to the soul after death. In particular, he finds problematic the idea of the eternal reunion with our loved ones. The idea is challenging due to theoretical difficulties in understanding certain concepts. First, our notions of love are not very clear or systematic, and we tend to love or like various people in our lifetime, yet these people may not like each other and may not be willing to spend time together in their afterlife. Second, we do not have a clear picture of how our earthly identity, responsible for our affections, may be preserved in the afterlife ${ }^{55}$ The problem of the continuity of one's identity after death is also connected with an even more compelling issue. It is not clear how we could preserve the memories from our mundane existence, which renders the idea of eternal punishment rather unjust. If in the afterlife we

47 Ibid., p. 18.

48 Ibid.

49 Ibid., p. 19.

50 Ibid., p. 21.

51 Ibid.

52 Ibid., p. 153.

53 Ibid.

54 Ibid.

55 Ibid. 
do not have a strong sense of identification with our earthly existence, we may not feel responsible for our deeds we committed as humans on earth. ${ }^{56}$

This theme of religious connotations and explanations reemerges in John C.'s thoughts about his own imminent death. His current experience of loneliness is reinforced in his dream about passing into the underworld. In this dream, he had a feeling as though he had already died but could still look at his dead body. ${ }^{57}$ In his analysis of the dream, he recollects the myth of Eurydice and Orpheus. ${ }^{58}$ John C. interprets the story of Eurydice and Orpheus as a story about the solitariness of death. The protagonist observes that humans have no power to choose their companions in the moment of death. Death is a passage we have to face alone, doomed to "our allotted fate." 59 Although this vision is rather tenebrous and sorrowful, he finds mythological explanations more adequate than the more optimistic religious ones: "The Greek view of the afterworld strikes me as truer than the Christian vision. The afterworld is a sad and subdued place." ${ }^{\prime 60}$

Yet, despite the undoubtedly bleak atmosphere of John C's theoretical considerations, which has been commented upon by numerous critics, I want to argue that John C.'s views are not entirely gloomy. He does have one source of consolation - art and particularly literature, which offers a more inspiring outlook on life. Although John C. tends to reject common religious beliefs about the afterlife, he notices some uplifting aspects of human existence when he discusses "spirituality" in the secular context. Still, these comforting views are not grounded in any ideological opinions, but mostly in the inspiring nature of art. What gives John C. some consolation and motivation to persevere in his life is artistic creation. In his "soft opinions," he draws the reader's attention to the restorative power of art, including music and literature. He focuses on the expressive power of music in conveying emotions and feelings. For him, music "gives shape and habitation to feeling, not in space but in time." ${ }^{61}$ He gives an example of Bach's music as a source of joy in his life, which comes to him "as a gift, unearned, unmerited, for free." 62 The protagonist tries to find comfort and hope in music, although this consolation is found mostly on aesthetic grounds rather than through logical reasoning: "The best proof we have that life is good, and therefore that there may perhaps be a God after all, who has our welfare at heart, is that to each of us, on the day we are born, comes the music of Johann Sebastian Bach." 63 John C. also attributes special value to the music of Romanticism, due to its mesmeric capacity for uplifting human emotions: "Romantic music seeks to recover a lost state of raptness (...), a state of exaltation in which the human shell will be shed and one will become pure being or pure spirit." ${ }^{64}$ As usual in Coetzee's fiction, this

\footnotetext{
56 Ibid., p. 154.

57 Ibid., p. 157.

58 Ibid., p. 159.

59 Ibid.

60 Ibid.

61 Ibid., p. 130.

62 Ibid., p. 221.

63 Ibid.

64 Ibid., p. 137.
} 
reference to spirituality most likely has only metaphorical meaning, signifying the elevated state of artistic ravishment rather than evoking any "orthodox religious beliefs." $" 65$

John C. believes in the universal appeal of music. He observes similarities in human and animal approaches to music since he claims that birds' songs are truly expressions of their self rather than automatic reactions. He rejects the Cartesian treatment of animals as simple machines, in which birds' songs are believed to have a merely biological function: "What Cartesian nonsense to think of birdsong as pre-programmed cries uttered by birds to advertise their presence to the opposite sex." ${ }^{66}$ Instead, John C. treats bird-cries as the expressions of elation accompanying genuinely authentic existence: "Each bird-cry is a full-hearted release of the self into the air, accompanied by such joy as we can barely comprehend. I! says each cry: I! What a miracle!" 67 In singing, creatures may find the freedom of expressing their true nature and creativity: "Singing liberates the voice, allows it to fly, expands the soul." 68

Another branch of art in which John C. finds some encouragement is literature. The protagonist expresses his appreciation especially for Russian literature, which in his opinion undertakes problems of paramount importance for ethical and existential debates. Despite popular opinion that Leo Tolstoy "succumbed to simplification and didacticism," John C. believes Tolstoy's late prose to be exemplary literature written by an artist who searched for an answer to the question "how to live."70 John C. also values Dostoevsky's prose, especially when he recollects Dostoevsky's The Brothers Karamazov. In this Russian novel, John C. recognizes an accurate representation of the human condition in the world. He foregrounds the part of Dostoevsky's narrative in which Ivan Karamazov's hands back "his ticket of admission to the universe God has created." "Although John C. remains rather sceptical about the logical power of Ivan's reasoning, he sympathises with his state of mind. The protagonist in Diary of a Bad Year is impressed by the rhetoric of Ivan's monologue and the emotive impact it may have on the reader. The monologue is highly valued by John $\mathrm{C}$. due to its adequate presentation of human suffering in the face of the cruelty experienced in the world: "Far more powerful than the substance of his argument, which is not strong, are the accents of anguish, the personal anguish of a soul unable to bear the horrors of this world." 72 John C. opines that reading Russian literature may help us become morally stronger due to important ethical messages inherent in these works: "[Tolstoy and Dostoevsky] annihilate one's impurer pretensions; they clear one's eyesight; they fortify one's arm." ${ }^{, 73}$ This appreciation for literature in the last entry

\footnotetext{
65 D. Attridge, op. cit., p. 180.

66 J.M. Coetzee, op. cit., p. 132.

67 Ibid.

68 Ibid.

69 D. Attwell, op. cit., p. 218.

70 J.M. Coetzee, op. cit., p. 193.

71 Ibid., p. 223.

72 Ibid., p. 225.

73 Ibid., p. 227.
} 
in John C.'s diary is suffused with a rather melancholy tone. In Abbott's discussion on this entry, Dostoevsky is described as an artist "whose torment and lack of serenity marked his work right up to his last unfinished novel." ${ }^{.74}$ Nonetheless, John C.'s evaluation of this Russian novelist may be read as a manifestation of the power of literature, which would agree with Coetzee's assessment of Dostoevsky's prose. In Giving Offense: Essays on Censorship, Coetzee reads Dostoevsky "as an artist who takes seriously the project of 'exploring the darker areas of human experience." "'75 As pointed out by Attwell ${ }^{76}$, John C. associates Russian literature with "vatic speech," which he correlates with the highest value of literature. The power of literature does not necessarily come from a veridical representation of the world. Instead, John C. links the authority of poetry and art to the ability to speak "vatically." 77 This orientation may be treated as representative for Coetzee's works, in which, in the words of David Attwell, "the narrators speak most powerfully from strange sources - from dreams, wounded bodies and defenceless longings." opinions" from the "Secondary Diary" are "a movement away from politics and toward rhetoric and story-telling." "more open to vatic promptings and there is a power of feeling in some of the more confessional entries." ${ }^{80}$ These more personal opinions encourage the reader to "suspend secular, empirical reasoning (...) and to use other modes of interfacing with the world as a way of apprehending a type of mystery that is most often invoked around topics like music, art, love, emotion, thought, and death," as explicated by Benjamin Ogden. ${ }^{81}$ It produces an overall interpretation of the novel as espousing what Stuart Murray calls "an indictment of Enlightenment reason and calculative thinking." 82 The unusual divisions within the novel into three sections also "explicitly defy, reform, and to some degree reinvent the realist novel," focusing on the very question of how a work of fiction "comes into being." 83 The innovative framework of the novel gives space to multifarious voices that can be freely expressed in the narrative. This inclusion of multiple perspectives, sometimes polemical or even contradictory, is praised by Evy Varsamopoulou in her article Timely Meditations: Reflections on the Role of the Humanities in J.M. Coetzee's Elizabeth Costello and Diary of a Bad Year as one of the most significant merits of fiction, exemplified by Coetzee's works. ${ }^{84}$

74 H.P. Abbott, op. cit., p. 196.

75 J.M. Coetzee, Giving Offense: Essays on Censorship. Chicago, London, 1996, p. 74 [in:]

J. Geertsema, op. cit., p. 215.

76 D. Attwell, op. cit., p. 220.

77 J.M. Coetzee, op. cit., p. 151.

78 D. Attwell, op. cit., p. 219.

79 St. Murray, op. cit., p. 332.

${ }^{80}$ D. Attwell, op. cit., p. 219.

${ }^{81}$ B.H. Ogden, op. cit., p. 478.

82 St. Murray, op. cit., p. 332.

${ }^{83}$ B.H. Ogden, op. cit., p. 466.

${ }^{84}$ E. Varsamopoulou, Timely Meditations: Reflections on the Role of the Humanities in J.M. Coetzee's Elizabeth Costello and Diary of a Bad Year, "Humanities" 2014, Issue 3. 
The important role of literature may also be illustrated in the final outcome of the acquaintance between the main characters in Diary of a Bad Year. In the process of working on John C.'s manuscript, Anya and John C. help each other tackle important challenges in their lives. The most conspicuous result for John C. is the publication of his newest book, which had been typed by Anya before it was sent to the publishing house in Germany. This positive outcome of their cooperation in the process of typing the manuscript results in what constitutes the first sections of the novel, which occupy a significant amount of space in Diary of a Bad Year. Still, what may be even more appreciated is John C.'s decision to write down also his more subjective and more emotional stories, as he was encouraged to do by Anya. This act of extending his set of written opinions is interpreted by Ogden as illustrating how “Anya 'annihilates' John C's 'impurer pretentions' (his bleak nihilism, his unwillingness to test his hand at storytelling for fear he has lost the gift.)" 85 The relation between the novelist and Anya also has a beneficial influence on the woman's life. For Anya, the acquaintance with John C. results in her decision to terminate her unsuccessful relationship with unscrupulous Alan. Anya's decision, with its positive transformative consequences for her future life, may be taken to demonstrate the distinguishing quality of fiction. It appears to support Abbott's thesis that "the greatest potential for narrativity" may lie in depicting "the transformation of a human being over time." 86 The appreciation for literature may be in line with Coetzee's own point of view, as outlined by Derek Attridge in his introduction to Coetzee's collection Inner Workings. Literary Essays 2000-2005. According to Attridge, Coetzee's essays constitute "a substantial and significant contribution to the continuing discussion of literature's place in the lives of individuals and cultures." 87

To recapitulate, Diary of a Bad Year is an unconventional novel, which uses the tripartite composition to question the authority of a singular perspective. It may be stated that the novel presents the main protagonist's views upon social, ethical, political, and scientific matters in a rather pessimistic way. Yet, the validity of this outlook upon human life presented in the most spacious essayistic sections in the first part of the novel is undermined by the general framework of the narrative, in which John C.'s opinions are questioned when juxtaposed against the alternative views voiced by the other characters. Art, especially music and literature, are a source of consolation for John C. in his more personal opinions revealed in the second half of the novel. He treats these areas of human activity as a source of solace and a motivation for improvement in human life. The story narrated in the novel may also reinforce the image of the positive role of literature in human existence. As a result of their cooperation during the manuscript preparation, both Anya and John C. manage to improve their lives due to their challenging yet meaningful decisions and the accomplishment of the project that brought them together - the publication of John C.'s book.

${ }^{85}$ B.H. Ogden, op. cit., p. 481.

${ }^{86}$ H.P. Abbott, op. cit., p. 195.

87 D. Attridge, Introduction [in:] J.M. Coetzee, Inner Workings. Literary Essays 2000-2005, New York 2007, p. x. 


\section{References}

Abbott H.P., Time, Narrative, Life, Death, \& Text-Type Distinctions: The Example of Coetzee's Diary of a Bad Year, "Narrative" 2011, Issue 2.

Attridge D., Introduction [in:] J.M. Coetzee, Inner Workings. Literary Essays 20002005, New York 2007.

Attridge D., J.M. Coetzee and the Ethics of Reading, Chicago-London 2004.

Attwell D., Mastering Authority: J.M. Coetzee's Diary of a Bad Year, "Social Dynamics" 2010, Issue 1.

Bakhtin M. The Dialogic Imagination: Four Essays by M.M. Bakhtin. ed. M. Holquist, Austin 1981.

Coetzee J.M., Giving Offense: Essays on Censorship. Chicago, London, 1996.

Coetzee J.M., Diary of a Bad Year, New York 2008.

Dancer T., Between Belief and Knowledge: J.M. Coetzee and the Present of Reading, "Minnesota Review" 2011, Issue 77.

Falcato A., Modernist Realism and its Enemies: John Coetzee and Philosophy, "Aisthema, International Journal" 2015, Issue 2.

Geertsema J., Diary of a Bad Year (2007) [in:] A Companion to the Works of J.M. Coetzee, ed. T. Mehigan, Rochester (NY) 2011.

Hobbes Th., Leviathan or, The Matter, Form, and Power of a Commonwealth, London 1839.

Isom R., "Do you think I can't read between the lines?": Discourse of the Unsaid in J.M. Coetzee's Diary of a Bad Year, "The Journal of Commonwealth Literature" 2018, Issue 1.

Lear J., Ethical Thought and the Problem of Communication [in:] J.M. Coetzee and Ethics: Philosophical Perspectives on Literature, eds. A. Leist, P. Singer, New York 2010.

López, M. J., Acts of Visitation: The Narrative of J.M. Coetzee, Amsterdam 2011.

Macaskill, B., Charting J.M. Coetzee's Middle Voice, "Contemporary Literature" 1994, Issue 3 (Autumn 1994).

Maziarczyk, G, An Utterly Contemporary Work of Fiction? J.M. Coetzee's Diary of a Bad Year [in:] Generic Instability and Identity in the Contemporary Novel, eds. M. Gonzalez, M.O. Pittin-Hedon, Newcastle upon Tyne 2010.

McDonald P.D., The Ethics of Reading and the Question of the Novel: The Challenge of J.M. Coetzee's Diary of a Bad Year, "Novel: A Forum on Fiction” 2010, Issue 3.

McHale B., Postmodernist Fiction, London-New York 1987.

Murray St., Allegories of the Bioethical: Reading J.M. Coetzee's Diary of a Bad Year, "Journal of Medical Humanities" 2014, Issue 35.

Napolitano J.D., "Mr Melancholy and Mr Magpie": The Lives of Animals in J.M. Coetzee's Diary of a Bad Year, "Safundi: The Journal of South African and American Studies" 2010, Issue 1-2.

Ogden B.H., The Coming into Being of Literature: How J.M. Coetzee's Diary of a Bad Year Thinks through the Novel, "Novel: A Forum on Fiction" 2010, Issue 3. 
Szczepański J., Homo homini deus est - homo homini lupus est. Kilka uwag o naturze ludzkiej wedtug Hobbesa, "Archiwum Historii Filozofii i Myśli Społecznej” 2013, Issue 58.

Varsamopoulou E., Timely Meditations: Reflections on the Role of the Humanities in J.M. Coetzee's Elizabeth Costello and Diary of a Bad Year, "Humanities" 2014, Issue 3.

Woessner M., Beyond Realism. Coetzee's Post-Secular Imagination [in:] Beyond the Ancient Quarrel. Literature, Philosophy, and J.M. Coetzee, eds. P. Hayes, J. Wilm, Oxford 2017. 